Pak. j. sci. ind. res. Ser. A: phys. sci. 201356 (2) 86-92

\title{
A Study on the Production of Biodiesel from Used Frying Oil
}

\author{
Mehmood Abbas ${ }^{\mathrm{a}}$, Farooq Ahmad ${ }^{\mathrm{a} *}$, Adnan Skhawat Alia, Maqsood Ahmed ${ }^{\mathrm{a}}$, Muhammad Farhana, \\ Syed Ahtisham Shabbir ${ }^{b}$, Aqsa Iftikhar ${ }^{a}$ and Nazish Mohy-u-Din ${ }^{a}$ \\ aSustainable Development Study Centre, GC University, Lahore, Pakistan \\ ${ }^{\mathrm{b}}$ Directorate General of Health, Lahore, Government of Punjab, Pakistan
}

(received February 28, 2012; revised December 29, 2012; accepted January 4, 2013)

\begin{abstract}
The study was carried out to utilize waste frying oil for biodiesel production because it is cheap, easily available and renewable raw material. The used frying oil was analyzed for water contents $(0.43$ $\%)$, iodine value (52), sponification value (205), free fatty acids (8.7 \%) and acid value (0.8 mg KOH/g). Esterification and transesterification were conducted to convert free fatty acids and triglycerides to methyl ester (biodiesel), respectively. One-step and two-step transeterification reactions were carried out to measure the efficiency of these processes for biodiesel production. The biodiesel produced from used frying oil was examined for flash point $\left(185^{\circ} \mathrm{C}\right)$, kinematic viscosity $\left(4.86 \mathrm{~mm}^{2} / \mathrm{s}\right)$ and specific gravity $(0.884 \mathrm{~g} / \mathrm{mL})$ that were meeting the limits of ASTM and Thai standards. Hence, it was proved to be a useful technique for biodiesel production at commercial scale.
\end{abstract}

Keywords: biodiesel, esterification, transesterification, waste cooking oil, renewable raw material

\section{Introduction}

Worldwide oil consumption was 3571.6 million tons, in 2000 but in 2010, the consumption reached 4028.1 million tons, with average annual increase of 3.1\%. According to British Petroleum Statistical Review of World Energy (2011), the world oil reserves were estimated 188.8 million tons with a reserve to production ratio of 46.2 years at the end of 2010 (Goldemberg, 2008). The first diesel engine that ran on vegetable oil was built in 1893 by Rudolf Diesel and gave the idea of using vegetable oil as a transportation fuel. Current energy demand is hardly fulfilled by conventional energy resources such as petro-diesel, coal and natural gas. The reserves of petroleum fuel will deplete in near future (Sheehan et al., 1998). Petroleum price has not only been increasing but also causing environmental pollution by producing hazardous gases due to incomplete combustion of these fuels (Marchetti et al., 2007). Balance between economic, agriculture and environmental development could be made by using alternative fuel which should be economically competitive, technically feasible, readily available and environmentally acceptable. Biodiesel synthesized from renewable raw material has all these properties (Meher et al., 2006). In the recent years particular focus has been emphasized on biodiesel production from cheaper

*Author for correspondence; E-mail: fagondal82@yahoo.com sources such as vegetable oil (Balat, 2008) because it is renewable, eco-friendly, biodegradable and non toxic in nature. Moreover, biodiesel is a clean fuel having no sulphur emissions and lower heat of combustion than petro-diesel (Srivastava and Prasad 2000). Biodiesel produced from animal fat and used frying oil is ecofriendly and good alternative to diesel fuel (Demirbas, 2005). Recently scientists all over the world are trying to produce more and more biodiesel because it can be used as substitute for petro-diesel without the modification in diesel engines (Demirbas, 2002). Biomass, vegetable oil, animal fat and used frying oil can be used to produce biodiesel by reacting with alcohol (methanol or ethanol) and strong base catalyst such as potassium or sodium hydroxide (Kalam and Masjuki 2002).

Renewable raw material such as oil could be converted into its corresponding fatty ester (biodiesel) by transesterification reactions. Transesterification process can proceed with or without alkali catalyst by using primary or secondary monohydric aliphatic alcohols. However, for the production of biodiesel, various types of oils (as raw material), homogeneous catalysts (potassium hydroxide, sodium hydroxide, sulphuric acid and supercritical fluids), heterogeneous catalysts and enzyme (lipase) can be used (Marchetti et al., 2007).The blend of biodiesel with petro-diesel could also be used in transport sector. The blend of biodiesel 
are denoted as Bxx, where $\mathrm{xx}$ shows the quantity of biodiesel blended with petro-diesel. For units, B100 is referred to $100 \%$ biodiesel and B80 is referred to $80 \%$ biodiesel and 20\% petro-diesel and so on (Demirbas, 2007).

Used frying oil is the residue which can be collected from restaurants, kitchens and food processing factories for the production of biodiesel. It is not recommended to be used again for cooking or frying purpose. Normally it is disposed in water bodies, where it is not only causing water pollution but also causing harm to aquatic organisms. Used frying oil can be a good option as raw material, because its price is 2 to 3 times lower than fresh vegetable oils which in turn reduce the production cost of biodiesel (Hameed et al., 2009). Although the physical and chemical characteristics of used frying oil are different from fresh edible oil but both oils can be transformed into biodiesel by applying same method i.e. transesterification reaction by alkali catalyst, acid catalyst or using enzymes. The used frying oil can be effectively converted into biodiesel by two-step transesterification reaction. The two-step transesterification reaction consists of alkali catalyzed reaction, and acid catalyzed reaction. The properties of biodiesel produced from used frying oil are certainly similar to those produced from their respective fresh vegetable oil (Loh et al., 2006).

The present study was conducted to measure conversion efficiency of used frying oil to biodiesel. Used frying oil was analyzed before its conversion to biodiesel to measure its suitability for biodiesel production. Biodiesel was analyzed after its production from used frying oil and compared with ASTM standards (2002). Comparison of yield of one-step and two-step transesterification reactions was another part of the study.

\section{Materials and Methods}

Collection of samples. Used frying oil was purchased from two different chicken frying shops from different locations of Shahdara Town, Lahore that was repeatedly used for frying from early morning to mid night and on closure of the restaurant it was put into a plastic can for sale or thrown in sewage drain. The price of used frying oils was 0.33 US $\$ / L$. The oil sample was collected in plastic bottles and transferred to laboratory for further processing. The collected sample was contaminated with suspended carbon particles and water content. Sieving and filtration were done to remove food contents and suspended carbon particles.
Analytical procedures. Before transesterification of the oil to methyl esters all impurities were removed before its conversion to biodiesel. For removing large solid particles a sieving plate with mesh size $170 \mathrm{~mm}$ was used and to remove all suspended particles Whattman filter paper was used. Used frying oil sample was heated at $60^{\circ} \mathrm{C}$ for $30 \mathrm{~min}$ to remove water content. Fatty acid profile was analyzed by gas chromatography mass spectrometry (GC-MS, Shimadzu GC-14-A). Properties of used frying oil sample such as, acid value free fatty acid value, iodine value and saponification value were analyzed by methods of Raie (2008).

Experimental setup. Sodium methoxide was prepared by mixing $\mathrm{NaOH}$ and pure methanol. Sodium hydroxide was used $1 \%$ wt (dry weight basis) to oil and methanol was used $10 \%$ (dry weight basis) to used frying oil with molar ratio 6:1 (Charoenchaitrakool and Thienmethangkoon, 2011). The measured amount of $\mathrm{NaOH}$ and pure methanol were mixed in beaker and stirred for $30 \mathrm{~min}$.

Transesterification reaction was carried out by mixing oil with sodium methoxide to convert fatty acids (triglycerides) of used frying oil to methyl esters (Biodiesel). Sodium methoxide was mixed in used sample when its temperature reached to $60{ }^{\circ} \mathrm{C}$ and stirred continuously for $30 \mathrm{~min}$. The mixture was then allowed to stand in separating funnel for at least $8 \mathrm{~h}$. Two layers were produced, (a) with glycerol in the bottom and (b) methyl ester at the top. Upper layer was mixed with hexane to dissolve methyl esters, and then hexane was separated by distillation afterwards to get pure biodiesel (Ahmad et al., 2009).

Two-step catalyzed process was used i.e. esterification and transesterification. In the esterification process, free fatty acids (FFA) were reduced in the used frying oil using sulphuric acid as a catalyst. The optimum conditions were obtained using molar ratio of methanol to used frying oil $6: 1$ with $0.68 \%$ wt of sulphuric acid and reaction time $1 \mathrm{~h}$ at $51^{\circ} \mathrm{C}$. In the transesterification reaction, methanol and alkali $(\mathrm{NaOH})$ the catalyst was used to convert triglyceride portion of the used frying oil to methyl ester and glycerol. The optimum conditions were obtained using molar ratio of methanol to used sample 9:1 with $1 \%$ wt of base catalyst and reaction time $1 \mathrm{~h}$ at $55{ }^{\circ} \mathrm{C}$ (Charoenchaitrakool and Thienmethangkoon, 2011; Lotero et al., 2005).

The final product of methyl ester was identified with the help of thin layer chromatography (TLC) at Applied Chemistry Research Centre, Pakistan Council of 
Scientific and Industrial Research (ACRC-PCSIR) Laboratories, Lahore. Thin layer chromatogram was prepared with particular length, width and thickness $(20 \mathrm{~cm} \times 20 \mathrm{~cm} \times 0.25 \mathrm{~mm})$ by utilizing water and silica gel. The plate was air dried and activated on heating at $105^{\circ} \mathrm{C}$ in the oven for $1 \mathrm{~h}$. Biodiesel was dissolved in pure $n$-hexane as $n$-hexane, and diethyl ether $(80: 20)$ were used as solvent system. The 2, 7dichlorofluorescein as non-destructive locating agent was required to see colour bands (purple-yellow) under ultra violet light of $366 \mathrm{~nm}$ wavelength.

\section{Results and Discussion}

Water content. Water content of oil sample was removed up to $0.43 \%$ by heating for $35 \mathrm{~min}$ (Table 1 ). The water content present in the used oil sample decreased the efficiency of the transesterification process, because it decomposes the esters present in the oil and results in the saponification of oil by base catalyst. Presence of high water content in the oil can be tackled by acid catalyst, which increases the efficiency of transesterification process named as two content step transesterification process. Water in pretreated used frying oil was determined to be $0.1 \%$ by weight (Charoenchaitrakool and Thienmethangkoon, 2011). Minimum water content and free fatty acid content in oil were very important for getting optimal results in the process of transesterification. Basic catalyst can only be utilized in transesterification process, when there is low water and free fatty acid contents. If the water content and fatty acid are high then two-step transesterification process is suitable in which the first-step is carried out with acid catalyst and the second-step with basic catalyst. Reaction rate can be increased by increasing reaction time (Ahmad et al., 2009). In this current study, both processes were used to measure their efficiency.

Iodine value. Iodine value can be used to measure the unsaturation of oils. It is the percentage of iodine in centi-grams which $1 \mathrm{~g}$ of sample absorbed. Iodine value

Table 1: Analysis of pretreated frying oil sample

\begin{tabular}{ll}
\hline \hline Parameters tested & Results \\
\hline Water content (\%) & 0.43 \\
Nature of food (fried) & Chicken meat \\
Iodine value (mg/g) & 52 \\
Saponification value (mg/g) & 205 \\
Free fatty acid (\%) & 8.7 \\
Acid value (mg KOH/g) & 0.8 \\
\hline \hline
\end{tabular}

of used frying oil sample was calculated to be $52 \mathrm{mg} / \mathrm{g}$ (Table 1). Balat and Balat (2010) calculated iodine value $35-61 \%$ for palm oil and $110-143 \%$ for sunflower oil. According to Oliveira et al. (2010) the oil showed iodine index $7.21 \mathrm{~g} / 100 \mathrm{~g}$. Low value of iodine indicated lower unsaturated compounds of carbon and the biodiesel produced from that oil was resistant to oxidation process.

Saponification value. The process of saponification of sodium soap obtained from vegetable oil can be described in the following chemical equation:

vegetable oil $+\mathrm{NaOH} \rightarrow \mathrm{RCOONa}+$ glycerin (Demirbas, 2002).

The saponification value of used frying oil was measured to be $205 \mathrm{mg} / \mathrm{g}$ (Table 1). Demirbas (2009b) calculated the sponification value 188.2. High level of saponification required that sample must be esterified with sulphuric acid with methanol. If the free fatty acid level exceeds $0.5 \%$ by weight then the saponification reduces the formation and yield of methyl ester (biodiesel) and hindered settling of products obtained (Canakci and Gerpen, 2001).

Acid and free fatty acid values. The free fatty acid (FFA) value is the amount of milligram of $\mathrm{KOH}$ needed to neutralize fatty acids in $1 \mathrm{~g}$ of oil. The FFA value measured in used frying oil of current study was $8.7 \%$ (Table 1). Balat and Balat (2010) calculated FFA value 5.6 for frying oil and $>20$ for waste palm oil while Berrios et al. (2010) measured FFA value 2.14 for used frying oil. High free fatty acid content can be esterified using acid catalyst. Good quality methyle esters can be obtained by basic catalyst if free fatty acid content remained lower than $1.0 \mathrm{wt} \%$ (Meng et al., 2008).

The acid value is the amount in milligram (mg) of aqueous potassium hydroxide $(\mathrm{KOH})$ in $1 \mathrm{~g}$ of oil to neutralize the total free fatty acids. The acid value of sample studied was determined to be $0.8 \mathrm{mg} \mathrm{KOH} / \mathrm{g}$ of oil (Table 1). Berrios et al. (2010) measured acid value $0.14 \mathrm{mg}$ for used frying oil. In the process of base catalyzed transesterification the acid value of the oil must be less than $1 \mathrm{mg}$ (Demirbas, 2009c). If the acid value exceeds $1 \mathrm{mg}$ then additional alkali must be used to neutralize the free fatty acids (Canakci and Ozsezen, 2005).

Fatty acid composition and yield of reaction. Fatty acid composition of used frying oil was analyzed by gas chromatography. It was found that the used frying oil contained $0.1 \mathrm{wt} \%$ myristic acid, $7.88 \mathrm{wt} \%$ palmitic 
acid, $0.35 \mathrm{wt} \%$ stearic acid, $54.54 \mathrm{wt} \%$ oleic acid, 28.96 wt\% linoleic acid, $7.546 \mathrm{wt} \%$ linolenic acid, $0.18 \mathrm{wt} \%$ arachidonic (Table 2). Charoenchaitrakool and Thienmethangkoon (2011) reported the percentage composition of fatty acids in waste frying oil as 1.1 wt $\%$ myristic acid, $25.8 \mathrm{wt} \%$ palmitic acid, $4.7 \mathrm{wt} \%$ stearic acid, $34.6 \mathrm{wt} \%$ oleic acid, $29.4 \mathrm{wt} \%$ linoleic acid, $2.5 \mathrm{wt} \%$ linolenic acid, and $0.2 \mathrm{wt} \%$ arachidonic acid. Demirbas (2009a) calculated fatty acid composition of waste cooking oil from sunflower seed oil as 6.8 wt\% C16:0 (palmitic acid), 3.7 wt\% C18:0 (stearic acid), 22.8 wt $\%$ C18:1 (oleic acid), 65.2 wt $\%$ C18:2 (linoleic) and $0.1 \mathrm{wt} \% \mathrm{C} 18: 3$ (linolenic).

In one-step transesterification process, the yield of biodiesel was calculated to be $88 \%$ with glycerine as a byproduct. In two-step process, the yield of biodiesel was higher (92\%) than one step process (Table 3). Formation of soap during one-step reaction was the reason of its low yield. However, in two-step reaction, sulphuric acid caused esterification of FFAs before biodiesel synthesis thus reducing the chances of soap formation. Zhang et al. (2003) described that high free fatty acid contents required to have pretreatment process in which the acid catalyst such as sulphuric acid was used to reduce the free fatty acid (FFA) contents.

Table 2. Percentage composition of fatty acids in used frying oil

\begin{tabular}{ll}
\hline \hline Fatty acid profile & Result (\%) \\
\hline C14:0 Tetradecanoic (myristic) & Traces (0.1) \\
C16:0 Hexadecanoic (palmitic) & 7.88 \\
C18:0 Octadecanoic (stearic) & 0.35 \\
C18:1 Octadecenoic (oleic) & 54.54 \\
C18:2 Octadecadienoic (linoleic) & 28.96 \\
C18:3 Octadecatrienoic (linolenic) & 7.546 \\
C20:0 Eicosanoic (arachidonic) & 0.18 \\
Total saturated fatty acids & 8.51 \\
Total unsaturated fatty acids & 91.046 \\
Others & 0.444 \\
\hline \hline
\end{tabular}

Table 3. Measurement of amount and yield of products from $200 \mathrm{~mL}$ of used frying oil

\begin{tabular}{lll}
\hline \hline Products of the processes & $\begin{array}{l}\text { One-step } \\
\text { process }\end{array}$ & $\begin{array}{l}\text { Two-step } \\
\text { process }\end{array}$ \\
\hline $\begin{array}{l}\text { Biodiesel produced (mL) } \\
\begin{array}{l}\text { Glycerin and other } \\
\text { byproduct (mL) }\end{array}\end{array}$ & 176 & 184 \\
Yield of biodiesel (\%) & 24 & 16 \\
\hline \hline
\end{tabular}

Quality assessment of biodiesel. One step and two step transesterification processes were used for the production of biodiesel from used frying oil under reaction conditions shown in Table 4.

In sample 1 (two-step process) the used frying oil was almost completely converted to biodiesel (methyl ester) and was according to ASTM standard (2002) of biodiesel because there were no fatty acids and glycerides found in final product (biodiesel). Biodiesel produced by one-step transesterification process (sample 2) contained fatty acids and glycerides along with methyl ester. Therefore, the biodiesel produced from used frying oil was of good quality by two-step transesterification process using acid and base catalyst than by using one-step transesterification process using base catalyst as the final product contained some amount of fatty acids and glycerides (Fig. 1).

Kinematic viscosity. Kinematic viscosity is the quotient of the dynamic viscosity divided by density $(\mathrm{Va} / \mathrm{d})$ at same temperature. The viscosity of biodiesel produced from used samples determined by ASTM D445 method was 4.86 at $40{ }^{\circ} \mathrm{C}$ (Table 5). Charoenchaitrakool and Thienmethangkoon (2011) reported the viscosity of biodiesel 4.61. Balat (2008) reported that the biodiesel has viscosity close to diesel fuel. Viscosity effects the injection equipment at the time of operation of fuel and at low temperature the increase in the viscosity effects fluidity of fuel. By increasing the temperature of reaction, viscosity decreased and miscibility of methanol and oil

Table 4. Optimization of reaction conditions for transesterification of used frying oil

\begin{tabular}{llll}
\hline \hline Reaction conditions & $\begin{array}{l}\text { One-step process } \\
\text { transesterification }\end{array}$ & \multicolumn{2}{c}{ Two-step process } \\
\cline { 3 - 4 } & $\mathrm{NaOH}$ & $\mathrm{H}_{2} \mathrm{SO}_{4}$ & $\mathrm{NaOH}$ \\
Catalyst & $3: 1$ & $6: 1$ & $9: 1$ \\
Methanol to oil ratio & 60 & 51 & 55 \\
Temperature $\left({ }^{\circ} \mathrm{C}\right)$ & 30 & 60 & 60 \\
Reaction time (min) & & & \\
\hline \hline
\end{tabular}




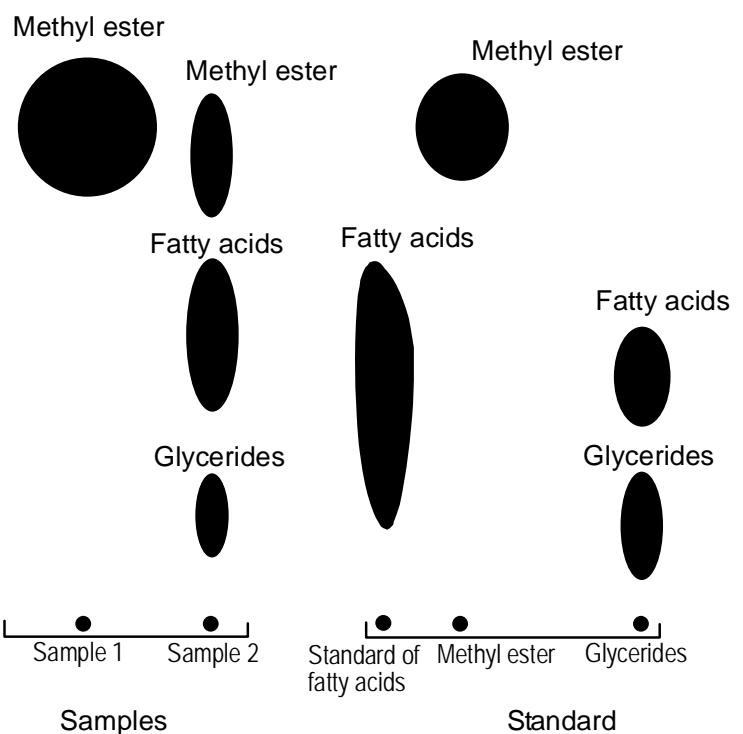

Fig. 1. Separation and identification of biodiesel (methyl ester) production from used frying oil by using solvent system at $n$-hexane to diethylether ratio of 80:20.

increased that ultimately increased the free fatty acid conversions (Park et al., 2010).

Flash point. Flash point is the temperature recorded on thermometer at the time of application that causes a distinct flash in the interior of cup. The flash point of biodiesel produced in this study was determined by ASTM D93 testing method and the value obtained was $185{ }^{\circ} \mathrm{C}$ (Table 5). Charoenchaitrakool and Thienmethangkoon (2011) reported the flash point of biodiesel was 160 . The ASTM D6751-02 standard for flash point of biodiesel is more than $130{ }^{\circ} \mathrm{C}$. Demirbas (2009c) reported the flash point for biodiesel prepared from waste cooking oil was $469 \mathrm{~K}\left(196^{\circ} \mathrm{C}\right)$.

Specific gravity. Specific gravity is the ratio of weight of given volume of material to weight of an equal volume of water. In this method both weights recorded in vacuum condition and the standard reference temperature for both, material and water was $60 \mathrm{~F}$. The specific gravity of biodiesel measured by ASTM D1298 testing method was $0.884 \mathrm{~g} / \mathrm{mL}$ (Table 5). The minimum values of specific gravity indicate the removal of heavy glycerine and thus completion of reaction (Sharma et al., 2008). Balat and Balat (2010) calculated the specific gravity of biodiesel $0.88 \mathrm{~g} / \mathrm{mL}$. Berrios et al., (2010) measured the specific gravity of biodiesel obtained from used frying oil in pressure system was $0.875 \mathrm{~g} / \mathrm{cm}$. Demirbas (2009c) measured density of biodiesel from waste cooking oil as 0.897 $\mathrm{kg} / \mathrm{L}$ at $288 \mathrm{~K} 0$.

\section{Conclusion}

Energy crises and environmental impacts of fossil fuel are forcing world to search its alternatives such as biofuels. Therefore, biodiesel production from cheaper raw material can be a fruitful technology. Used frying oil could be the suitable raw material otherwise it is disposed off in water bodies or soil causing environmental and health problems. Synthesis of biodiesel from this waste oil could be the best use of it. In the present study, biodiesel was produced from used frying oil by two methods and it was found that the biodiesel produced from two-step transesterification method gives good quality in comparison to one-step transesterification process as soap formation took place in one-step process. Properties of biodiesel such as kinematic viscosity, flash point and specific gravity were analyzed and found within ASTM (2002) standards limits for biodiesel.

\section{Recommendations}

* Repeated use of frying oil should be banned to avoid health risk and its market value could be

Table 5. Analysis of biodiesel produced from used frying oil and its comparison with international standards

\begin{tabular}{lllll}
\hline Properties of biodiesel & $\begin{array}{l}\text { Testing } \\
\text { methods }\end{array}$ & $\begin{array}{l}\text { Biodiesel of } \\
\text { this study }\end{array}$ & $\begin{array}{l}\text { ASTM } \\
\text { D6751 (2002) }\end{array}$ & $\begin{array}{l}\text { Thai Standard } \\
\text { EN 14214 (2004) }\end{array}$ \\
\hline $\begin{array}{l}\text { Kinematic viscosity at } \\
40^{\circ} \mathrm{C}\left(\mathrm{mm}^{2} / \mathrm{s}\right)\end{array}$ & $\begin{array}{l}\text { ASTM } \\
\text { D445 }\end{array}$ & 4.86 & $1.9-6.0$ & $3.5-5.0$ \\
Flash point $\left({ }^{\circ} \mathrm{C}\right)$ & $\begin{array}{l}\text { ASTM } \\
\text { D93 }\end{array}$ & 185 & $>130$ & $>101$ \\
Specific gravity $(\mathrm{g} / \mathrm{mL})$ & $\begin{array}{l}\text { ASTM } \\
\text { D1298 }\end{array}$ & 0.884 & - & $0.860-0.900$ \\
\hline \hline
\end{tabular}


created by using it for biodiesel production.

* Following results of current study for biodiesel production from used frying oil should be launched at commercial scale as it is an efficient, cheaper and feasible raw material.

* Further research is needed on conversion of used frying oil to biodiesel by using various catalysts to enhance its yield.

\section{Acknowledgement}

The authors acknowledge Sustainable Development Study Centre at Government College University Lahore for providing funding for this current study and Dr. Muhammad Zeeshan at Applied Chemistry Research Centre (ACRC), PCSIR Laboratories Lahore for guiding and providing testing facilities of oil and biodiesel. Authors are also thankful to Tahir Sattar and Ikram Hussain Arain, Chief Chemist at Southern Electric Power Company Limited, Lahore for their cooperation in biodiesel testing.

\section{References}

Ahmad, M., Zafar, M., Khan, M.A., Sultana, S. 2009. Biodiesel from Pongamia pinnata L. oil: A promising alternative bioenergy source, Part A: Energy Sources, 31: 1436-1442.

ASTM D6751 2002. Standard Specification for Biodiesel Fuel (B100) Blend Stock for Distillate Fuels. www.astm.org/DATABASE.CART/HISTORICAL D6751-02.htm. DOI: 10.1520/D6751-02.

Balat, M., Balat, H. 2010. Progress in biodiesel processing. Applied Energy, 87: 1815-1835.

Balat, M. 2008. Modeling vegetable oil viscosity. Energy Source, Part A: Recovery, Utilization and Environment Effects, 30: 1856-1869.

Berrios, M., Martin, M.A., Chica, A.F., Martin A. 2010. Study of esterification and transesterification in biodiesel production from used frying oils in a closed system. Chemical Engineering Journal, 160: 473-479.

Canakci M., Ozsezen A. N. 2005. Evaluating waste cooking oils as alternative diesel fuel. Gazi University Journal of Science, 18: 81-91.

Canakci, M., Van Gerpen, J. 2001. Biodiesel production from oils and fats with high free fatty acids, Transactions of the American Society of Agricultural Engineerings, 44: 1429-1436.

Charoenchaitrakool, M., Thienmethangkoon, J. 2011. Statistical optimization for biodiesel production from waste frying oil through two-step catalyzed process. Fuel Processing Technology, 92: 112-118.

Demirbas., A. 2009a. Production of biodiesel fuels from linseed oil using methanol and ethanol in noncatalytic SCF conditions. Biomass Bioenergy, 33: 113-118.

Demirbas., A. 2009b. Progress and recent trends in biodiesel fuels. Energy Conversion and Management, 50: 14-34.

Demirbas., A. 2009c. Biodiesel from waste cooking oil via base-catalytic and supercritical methanol transesterification. Energy Conversion and Management, 50: 923-927.

Demirbas., A. 2007. Importance of biodiesel as transportation fuel. Energy Policy, 35: 4661-4670.

Demirbas., A. 2005. Biodiesel production from vegetable oils via catalytic and noncatalytic supercritical methanol transesterification methods. Progress in Energy Combustion Science, 31: 466-487.

Demirbas A. 2002. Diesel fuel from vegetable oil via transesterification and soap pyrolysis. Energy Source, 24: 835-841.

Goldemberg., J. 2008. Environmental and ecological dimensions of biofuels. In: Conference on the Ecological Dimensions of Biofuels, Washington, D.C., USA.

Hameed, B. H., Goh C. S., Chin, L.H. 2009. Process optimization for methyl ester production from waste cooking oil using activated carbon supported potassium fluoride. Fuel Processing Technology, 90: 1532-1537.

Kalam M.A., Masjuki, H.H. 2002. Biodiesel from palm oil an analysis of its properties and potential. Biomass Bioenergy, 23: 471-479.

Loh, S.K., Choo, Y. M., Cheng, S.F., Ma, A. N. 2006. Recovery and conversion of palm olein derived used frying oil to methyl esters for Biodiesel. Journal Oil Palm Research, 18: 247-252.

Lotero, E., Liu, Y., Lopez, D.E., Suwannakarn, K., Bruce, D.A., Goodwin, J.G. 2005. Synthesis of Biodiesel via Acid Catalysis. Industrial \& Engineering Chemistry Research, 44: 5353-5363.

Marchetti, J.M., Miguel, V.U., Errazu, A.F. 2007. Possible methods for biodiesel production. Renewable and Sustainable Energy Reviews, 11: 1300-1311.

Meher, L.C., Sagar, V.D., Naik, S.N. 2006. Technical aspects of biodiesel production by transesterification; A review. Renewable and Sustainable Energy Review, 10: 248-268.

Menga, X., Chen, G., Wang, Y. 2008. Biodiesel production 
from waste cooking oil via alkali catalyst and its engine test. Fuel Processing Technology, 89: 851-857. Oliveira, J.F.G., Lucena, I.L., Saboya, R.M.A., Rodrigues, M.L., Torres, A.E.B., Fernandes, F.A.N., Cavalcante Jr, C.L., ParenteJr, E.J.S. 2010. Biodiesel production from waste coconut oil by esterification with ethanol: The effect of water removal by adsorption. Renewable Energy, 35: 2581-2584.

Park, Y.M., Lee, J.Y., Chung, S.H., Park, I.S., Lee, S.Y., Kim, D.K., Lee, J.S., Lee, K.Y. 2010. Esterification of used vegetable oils using the heterogeneous $\mathrm{WO}_{3} / \mathrm{ZrO}_{2}$ catalyst for production of biodiesel. Bioresource Technology, 101: 59-61.

Raie, M.Y. 2008. Oil, Fats and Waxes, $1^{\text {st }}$ edition, National Book Foundation, Islamabad, Pakistan.

Sharma, Y.C., Singh, B., Upadhyay, S.N. 2008. Advancements in development and characterization of biodiesel: A review. Fuel, 87: 2355-2373.

Sheehan, J., Cambreco, V., Duffield, J., Garboski, M., Shapouri, H. 1998. An overview of biodiesel and petroleum diesel life cycles. A Report by US Department of Agriculture and Energy, pp. 1-35, Washington, D.C., USA.

Srivastava, A., Prasad, R. 2000. Triglycerides-based diesel fuels. Renewable and Sustainable Energy Reviews, 4: 111-133.

Thai standard EN 14214. 2004. Biofuels Standard \& Regulations in Thailand. Thailand Institute of Scientific and Technological Research (TISTR). http://www.tistr.or.th.

Zhang, Y., Dube, M.A., McLean, D.D., Kates, M. 2003. Biodiesel production from waste cooking oil: Process design and technological assessment. Bioresource Technology, 89: 1-16. 